\title{
Financial Performance of Housing Finance Companies in India- A Study of Select Companies
}

\author{
Dr. M. Selvaraj ${ }^{1}$ V.Vimal Kumarie ${ }^{2}$ \\ ${ }^{1}$ Associate Professor of Commerce, Kanchi Mamunivar Government Institute for Postgraduate Studies and Research, \\ Puducherry, India \\ ${ }^{2} \mathrm{Ph} . \mathrm{D}$. Research Scholar of Commerce, Kanchi Mamunivar Government Institute for Postgraduate Studies and \\ Research, Puducherry, India
}

\begin{abstract}
Housing plays a crucial role in the growth and development of the Indian economy. The main objective of the study is to evaluate and compare the stability of housing finance companies in the current financial performance with future scenarios by using ratio analysis and this study is based on secondary data. The collected data has been analyzed efficiency, liquidity, revenues, and profitability ratio. Five housing finance companies were selected as a sample for the study. The period selected for the study from 2010 to 2020 period. The study concludes that according to the overall ranking of ratio analysis the HDFC (Housing Development Finance Corporation Limited) and HUDCO (Housing Urban Development Corporation Ltd) are the best housing finance companies in India.
\end{abstract}

Keywords: Financial Performance, Ratios, National Housing Bank, Reserve Bank of India.

\section{INTRODUCTION}

Housing plays a crucial role in the growth and development of the Indian economy by investing every rupee in housing and construction, 78 paise added to GDP (Gross Domestic Product) growth our nation. A housing finance company (HFC) is a part of a non-banking financial institution. It is committed to the business of financing for the purchase and development of houses that include acquiring a plot of lands for the construction of new houses. The Indian housing finance companies are under the control of RBI (Reserve Bank of India) and NHB-1987 (National Housing Bank) as per the Finance Act 2019.

There are several players in the housing finance field: however, the most significant contribution comes from SCBs Scheduled Commercial Banks and Housing Finance Company (HFCs). The housing finance space was growing healthy before the (Infrastructure Leasing \& Financial Services Limited (IL\&FS) and DHFL (Dewan Housing Finance Corporation Ltd) crisis. Due to the liquidity crunch and the coronavirus pandemic, the sector is impacted heavily. Hence there is a need to study the financial performance of these housing finance companies to know its impact.

Financial performance of the selected housing finance companies, analysis is the process of identifying the financial pros and cons of the housing finance companies by properly establishing the relationship between the items of financial statements. This helps in short-term and long-term forecasting and growth can be identified with the help of the financial performance analysis.

\section{LITERATURE REVIEW}

Meghna Sarda \& Ramesh Chandra babu, 2018 in their study titled "financial performance analysis of selected Indian NBFCs in housing finance" investigate the financial health of the NBFCs that are into housing finance. The companies that are listed in the recognized stock exchange have been selected for the study. Ratios under camel parameters are calculated, tabulated, and presented graphically. Also, statistical tools, ANOVA (f-test) have been used to check the hypothesis that checks the difference between the companies based on the analysis it founded that GRUH finance is ranked first in this study followed by GIC housing finance and dewan housing finance ltd. The last rank is secured by LICHFL.

Satyanarayana \& Ramu, 2019 in their study titled “ a comparative study between public and private housing finance companies (HFCs) in India" evaluate the financial performance of five public HFCs and five private HFCs in India for the period of 2009-2018.by using descriptive statistics in the form of means and a student t-test and with some financial ratios. They founded that regulatory measures and policy reforms the profitability and operating ratios significantly influenced the financial performance of public and private HFCs. 


\section{International Advanced Research Journal in Science, Engineering and Technology}

Vol. 8, Issue 6, June 2021

\section{DOI: $10.17148 / I A R J S E T .2021 .8623$}

K \& Ahuja, 2020 in their articles titled "financial performance of housing finance companies in India". Examine the financial operation of the housing finance company for the year 2014-2015 to 2018-2019. Selected housing finance companies are listed in the recognized stock exchange. They have used financial parameter like liquidity, solvency, valuation, and profitability ratio has been used for analyzing concluded that crest venture and India bulls are performing well in the term liquidity, in overall performance position India bulls performance is better, and in the investment crest venture perform better when it compares to other selected housing finance company.

\section{OBJECTIVE OF THE STUDY}

a) To analyze and compare the financial performance of the selected housing finance companies in India from the period of 2010-11 to 2019-20.

b) To make an overall ranking of the current financial position of the selected housing finance company as per the ratios computed.

c) To evaluate the stability of housing finance companies in the current financial performance with future scenarios.

\section{RESEARCH METHODOLOGY}

\section{A. Nature of the Research}

This paper is descriptive-analytical.

\section{B. Source of Data}

This study is based on secondary data. Collected from the Annual Reports of Housing Finance Companies, the NHB progress Reports, Journals, Business Articles, and Magazines, Research Papers have been viewed for the study.

\section{Sample of Companies Considered for study:}

The Companies which are listed in both NSE (National Stock Exchange) and BSE (Bombay Stock Exchange) and also granted a Certificate of Registration (COR) with permission to accept public deposits have been selected for the study. It includes

1. Housing Development Finance Corporation Limited

2. LIC Housing Finance Limited,

3. Dewan Housing Finance Limited,

4. PNB Housing Finance Limited,

5. HUDCO (Housing Urban Development Corporation Ltd).

D. Period of the Study:

The period of the study is ten years from 2010-11 to 2019-20.

E. Data Analysis and tools Applied:

In this study, research tables are used for presenting the data. Some selected parameters are:

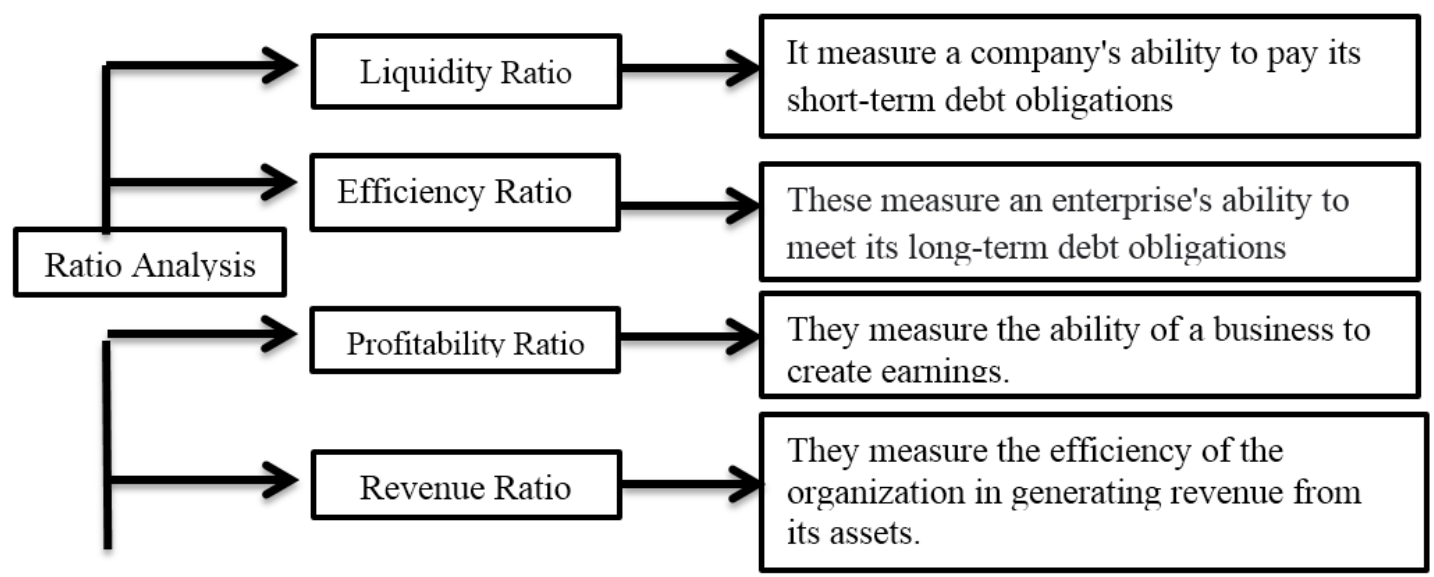

These ratios have been used for evaluating the financial operations and performance of selected HFCs.

\section{LIMITATIONS OF THE STUDY}

a) The study depends upon the secondary data only.

b) The period of study is limited to ten years only. 
International Advanced Research Journal in Science, Engineering and Technology

Vol. 8, Issue 6, June 2021

DOI: $10.17148 /$ IARJSET.2021.8623

c) The result of the study is restricted to the financial performance of selected housing finance companies only.

\section{DATA ANALYSIS \& INTERPRETATION}

A. Liquidity Ratio:

A.1. Current ratio:

- Current Ratio: Current Assets / Current Liabilities

Table 1: Showing the Current Ratios

\begin{tabular}{|l|l|l|l|l|l|l|l|l|l|l|l|l|}
\hline HFC & \multicolumn{10}{|c|}{ Years } \\
\cline { 2 - 15 } & $\begin{array}{l}\mathbf{2 0 1 0}- \\
\mathbf{1 1}\end{array}$ & $\begin{array}{l}\mathbf{2 0 1 1}- \\
\mathbf{1 2}\end{array}$ & $\begin{array}{l}\mathbf{2 0 1 2} \\
\mathbf{1 3}\end{array}$ & $\begin{array}{l}\mathbf{2 0 1 3}-\mathbf{1 4} \\
\mathbf{1 4}\end{array}$ & $\begin{array}{l}\mathbf{2 0 1 4} \\
\mathbf{1 5}\end{array}$ & $\begin{array}{l}\mathbf{2 0 1 5} \\
\mathbf{1 6}\end{array}$ & $\begin{array}{l}\mathbf{2 0 1 6} \\
\mathbf{1 7}\end{array}$ & $\begin{array}{l}\mathbf{2 0 1 7} \\
\mathbf{1 8}\end{array}$ & $\begin{array}{l}\mathbf{2 0 1 8} \\
\mathbf{1 9}\end{array}$ & $\begin{array}{l}\mathbf{2 0 1 9} \\
\mathbf{2 0}\end{array}$ & Average & Rank \\
\hline HDFC & 0.43 & 0.37 & 0.36 & 0.30 & 0.31 & 0.23 & 0.11 & 0.09 & 1.19 & 1.19 & 0.49 & 4 \\
\hline LIC & 0.09 & 0.07 & 0.12 & 0.19 & 0.17 & 0.17 & 0.17 & 0.09 & 1.08 & 1.09 & 0.32 & 5 \\
\hline Dewan & 1.45 & 0.72 & 0.44 & 0.47 & 0.30 & 0.44 & 1.31 & 0.66 & 0.73 & 0.87 & 0.74 & 3 \\
\hline PNB & 0.88 & 0.53 & 0.85 & 1.08 & 0.71 & 0.28 & 0.40 & 1.14 & 1.12 & 1.12 & 0.81 & 2 \\
\hline HUDCO & 0.71 & 1.04 & 0.81 & 1.57 & 0.89 & 1.11 & 1.27 & 0.63 & 1.18 & 1.20 & 1.04 & 1 \\
\hline
\end{tabular}

Source: Annual Reports of the respective concerns for the respective years.

\section{Interpretation:}

The current ratio is a ratio that measures a company's liquidity position to meet short-term obligations. The ideal current ratio for any company is 1:2 but from the above Table 1, it could be stated that the current ratio of five selected housing finance companies in an average of ten years HUDCO (1.42) is ranked the first position, PNB housing finance (0.81), Dewan Housing Finance (0.74), HDFC housing finance (0.46) and LIC housing finance company (0.32) respectively. It concluded that the HDFC, LIC, Dewan, and PNB housing finance companies are less than 1, which means that the company doesn't have enough liquid assets to cover its short-term liabilities.

\section{A.2. Operating cash flow ratio}

\section{Operating cash flow ratio: Cash flow from operation / Current Liabilities}

Table 2: Showing the Operating Cash Flow Ratios

\begin{tabular}{|c|c|c|c|c|c|c|c|c|c|c|c|c|}
\hline \multirow[t]{2}{*}{ HFC } & \multicolumn{12}{|c|}{ Years } \\
\hline & $\begin{array}{l}\text { 2010- } \\
11\end{array}$ & $\begin{array}{l}\text { 2011- } \\
12\end{array}$ & $\begin{array}{l}2012- \\
13 \\
\end{array}$ & $\begin{array}{l}2013- \\
14\end{array}$ & $\begin{array}{l}2014- \\
15\end{array}$ & $\begin{array}{l}2015- \\
16\end{array}$ & $\begin{array}{l}\text { 2016- } \\
17\end{array}$ & $\begin{array}{l}2017- \\
18\end{array}$ & $\begin{array}{l}2018- \\
19\end{array}$ & \begin{tabular}{|l}
$2019-$ \\
20 \\
\end{tabular} & Average & Rank \\
\hline HDFC & -0.29 & -0.33 & -0.26 & -0.20 & -0.21 & -0.19 & -0.26 & -0.29 & -0.11 & \begin{tabular}{|l|}
-0.10 \\
\end{tabular} & -0.22 & 1 \\
\hline LIC & -0.98 & -1.02 & -0.73 & -0.58 & -0.64 & -0.46 & -0.43 & -0.43 & -0.12 & -0.07 & -0.55 & 5 \\
\hline Dewan & 0.05 & 0.07 & 0.10 & 0.09 & -0.99 & -0.76 & -0.95 & -1.07 & -0.09 & 0.14 & -0.34 & 2 \\
\hline PNB & -0.72 & -0.57 & -0.15 & -0.16 & -0.11 & -0.91 & -0.96 & -0.29 & -0.22 & 0.13 & -0.40 & 4 \\
\hline HUDCO & 0.06 & 0.13 & 0.32 & -1.08 & -0.03 & -0.94 & -0.63 & -0.80 & -0.38 & -0.21 & -0.36 & 3 \\
\hline
\end{tabular}

Source: Annual Reports of the respective concerns for the respective years.

\section{Interpretation:}

The operating cash flow ratio measures the often, a company can clear current debts with cash generated within the same period. The ideal ratio is 1 . From the above table 2, it could be stated that the operating cash flow of five selected housing finance companies in an average of ten years HDFC (-0.22) is ranked the first position, Dewan Housing Finance (-0.34), HUDCO (-0.36), PNB housing finance (-0.40) and LIC housing finance company (-0.55) respectively. it found that all five selected housing companies are less than 1 , which indicates that the firm has not generated enough cash to cover its current liabilities in the same year.

Table3. Ranking on Liquidity Ratio

\begin{tabular}{|l|l|l|l|l|l|}
\hline Ratios & HDFC & LIC & DEWAN & PNB & HUDCO \\
\hline Average Current ratio & 0.46 & 0.32 & 0.74 & 0.81 & 1.04 \\
\hline
\end{tabular}


DOI: $10.17148 / I A R J S E T .2021 .8623$

\begin{tabular}{|l|l|l|l|l|l|}
\hline Rank & 4 & 5 & 3 & 2 & 1 \\
\hline Average operating cash flow ratio & -0.22 & -0.55 & -0.34 & -0.40 & -0.36 \\
\hline Rank & 1 & 5 & 2 & 4 & 3 \\
\hline Overall group ranking & 2.5 & 5 & 2.5 & 3 & 2 \\
\hline
\end{tabular}

On the overall ranking of 2 parameters in liquidity ratio, we can say that HDFC and Dewan (2.5) were at the first position followed by a HUDCO (2), PNB secured fourth place (3). LICHFL has the least (5) of all the HFCs because of its poor performance in terms of liquidity ratio.

\section{B. Efficiency Ratio:}

\section{B.1. Debt equity ratio:}

Debt Equity ratio : (Long Term Borrowings +Short Term Borrowings)/ Shareholders Equity

Table 4: Showing the Debt-Equity Ratios

\begin{tabular}{|c|c|c|c|c|c|c|c|c|c|c|c|c|}
\hline \multirow[t]{2}{*}{ HFC } & \multicolumn{12}{|l|}{ Years } \\
\hline & $\begin{array}{l}2010 \\
11\end{array}$ & $\begin{array}{l}2011- \\
12\end{array}$ & $\begin{array}{l}2012- \\
13\end{array}$ & $\begin{array}{l}2013- \\
14\end{array}$ & $\begin{array}{l}2014- \\
15\end{array}$ & $\begin{array}{l}2015- \\
16\end{array}$ & $\begin{array}{l}2016- \\
17\end{array}$ & $\begin{array}{l}2017- \\
18\end{array}$ & $\begin{array}{l}\text { 2018- } \\
19\end{array}$ & $\begin{array}{l}2019- \\
20\end{array}$ & Average & Rank \\
\hline HDFC & 3.65 & 4.07 & 3.64 & 3.33 & 3.29 & 3.34 & 3.98 & 2.66 & 4.72 & 4.86 & 3.75 & 2 \\
\hline LIC & 9.04 & 8.30 & 8.79 & 9.09 & 10.51 & 10.18 & 9.64 & 8.95 & 10.5 & 10.52 & 9.56 & 5 \\
\hline Dewan & 8.42 & 7.97 & 8.29 & 9.13 & 8.06 & 9.13 & 8.48 & 8.13 & 12.40 & -16.50 & 6.35 & 3 \\
\hline PNB & 7.51 & 7.02 & 8.65 & 8.58 & 7.24 & 7.89 & 4.39 & 5.86 & 9.66 & 8.6 & 7.54 & 4 \\
\hline HUDCO & 1.83 & 2.39 & 2.18 & 2.77 & 2.46 & 4.07 & 2.81 & 2.99 & 5.46 & 4.98 & 2.55 & 1 \\
\hline
\end{tabular}

Source: Annual Reports of the respective concerns for the respective years.

\section{Interpretation:}

The debt-to-equity ratio (D/E) is a ratio that shows the comparative proportion of debt and shareholders' equity used by the company's assets. The ideal ratio is 1.5 . Table 4, projects the increasing trend in the selected housing finance companies from the period 2011 to 20. The average of HUDCO (2.55) is good when compared to HDFC housing finance (3.76), Dewan housing finance (6.35) it shows the negative value of (-16.50) in 2019-2020 it indicates that interest rates on its debts that are finance company (7.54), and LIC housing finance (9.56) respectively. Therefore, the selected housing finance companies are more than the ideal value, which indicates that the housing finance companies are getting more of their financing by debt, which leads to potential risk.

\section{B.2. Shareholders equity ratio}

Shareholders equity ratio: Total shareholder equity/ Total Assets

Table 5: Showing the Shareholders Equity Ratio

\begin{tabular}{|c|c|c|c|c|c|c|c|c|c|c|c|c|}
\hline \multirow[t]{2}{*}{ HFC } & \multicolumn{12}{|l|}{ Years } \\
\hline & $\begin{array}{l}2010- \\
11\end{array}$ & $\begin{array}{l}\text { 2011- } \\
12\end{array}$ & $\begin{array}{l}2012- \\
13\end{array}$ & $\begin{array}{l}2013- \\
14\end{array}$ & $\begin{array}{l}2014- \\
15\end{array}$ & $\begin{array}{l}2015- \\
16\end{array}$ & $\begin{array}{l}\text { 2016- } \\
17\end{array}$ & $\begin{array}{l}2017- \\
18\end{array}$ & $\begin{array}{l}2018- \\
19\end{array}$ & $\begin{array}{l}2019- \\
20\end{array}$ & Average & Rank \\
\hline HDFC & 0.12 & 0.11 & 0.13 & 0.12 & 0.12 & 0.12 & 0.12 & 0.15 & 0.17 & 0.16 & 0.13 & 2 \\
\hline LIC & 0.08 & 0.09 & 0.08 & 0.08 & 0.07 & 0.07 & 0.07 & 0.07 & 0.08 & 0.08 & 0.08 & 4 \\
\hline Dewan & 0.09 & 0.09 & 0.09 & 0.08 & 0.08 & 0.07 & 0.09 & 0.08 & 0.00 & 0.00 & 0.07 & 5 \\
\hline PNB & 0.09 & 0.09 & 0.08 & 0.08 & 0.08 & 0.07 & 0.13 & 0.10 & 0.09 & 0.10 & 0.09 & 3 \\
\hline HUDCO & 0.24 & 0.22 & 0.24 & 0.24 & 0.26 & 0.22 & 0.24 & 0.20 & 0.15 & 0.16 & 0.22 & 1 \\
\hline
\end{tabular}

Source: Annual Reports of the respective concerns for the respective years.

\section{Interpretation:}

The shareholder equity ratio specifies how much companies generate assets by issuing equity shares rather than by taking on debt. Table 5 presents the average of HUDCO (0.22) using more equity for acquiring new assets when compared to PNB(0.09), LIC (0.07), Dewan (0.07), and HDFC (0.13). In general, almost, all selected housing 
International Advanced Research Journal in Science, Engineering and Technology

Vol. 8, Issue 6, June 2021

DOI: $10.17148 /$ IARJSET.2021.8623

finance companies are using equity and debt different proportions of leverage for generating an asset. But the lower ratio shows the more debt a company has used to pay for its assets.

Table 6. Ranking on the Efficiency Ratio

\begin{tabular}{|l|l|l|l|l|l|}
\hline Ratios & HDFC & LIC & DEWAN & PNB & HUDCO \\
\hline Average Debt equity ratio & 3.76 & 9.56 & 6.35 & 7.54 & 3.19 \\
\hline Rank shareholder & 2 & 5 & 3 & 4 & 1 \\
\hline $\begin{array}{l}\text { Average } \\
\text { equity ratio }\end{array}$ & 0.13 & 0.08 & 0.07 & 0.09 & 0.22 \\
\hline Rank & 2 & 4 & 5 & 3 & 1 \\
\hline Overall group ranking & 2 & 4.5 & 4 & 3.5 & 1 \\
\hline
\end{tabular}

On the overall ranking of 2 parameters in efficiency ratio, we can say that HUDCO(1) was at the first position followed by an HDFC (2), PNB (3.5), DEWAN(4), and LIC (4.5) has the least of all the HFCs because of its needful equity performance in terms of efficiency ratio.

\section{Profitability Ratio}

\section{C.1.Return on capital employed}

Return on capital Employed: Profit/Loss Before Exceptional, Extraordinary Items And Tax/ (Total assetsCurrent liabilities)

Table 7: Showing the Return On Capital Employed

\begin{tabular}{|c|c|c|c|c|c|c|c|c|c|c|c|c|}
\hline \multirow[t]{2}{*}{ HFC } & \multicolumn{12}{|c|}{ Years } \\
\hline & $\begin{array}{l}2010- \\
11\end{array}$ & $\begin{array}{l}2011- \\
12\end{array}$ & $\begin{array}{l}2012- \\
13\end{array}$ & $\begin{array}{l}2013- \\
14\end{array}$ & $\begin{array}{l}2014- \\
15\end{array}$ & $\begin{array}{l}2015- \\
16\end{array}$ & $\begin{array}{l}2016- \\
17\end{array}$ & $\begin{array}{l}2017- \\
18\end{array}$ & $\begin{array}{l}2018- \\
19\end{array}$ & $\begin{array}{l}2019- \\
20\end{array}$ & Average & Rank \\
\hline HDFC & 0.06 & 0.06 & 0.06 & 0.06 & 0.06 & 0.07 & 0.05 & 0.06 & 0.04 & 0.07 & 0.06 & 1 \\
\hline LIC & 0.03 & 0.02 & 0.02 & 0.02 & 0.02 & 0.02 & 0.03 & 0.02 & 0.02 & 0.02 & 0.02 & 4 \\
\hline Dewan & 0.02 & 0.02 & 0.02 & 0.02 & 0.02 & 0.02 & 0.05 & 0.02 & -0.04 & -1.53 & -0.14 & 5 \\
\hline PNB & 0.03 & 0.03 & 0.02 & 0.02 & 0.02 & 0.03 & 0.03 & 0.03 & 0.02 & 0.01 & 0.02 & 3 \\
\hline HUDCO & 0.05 & 0.05 & 0.05 & 0.04 & 0.04 & 0.04 & 0.03 & 0.03 & 0.03 & 0.03 & 0.04 & 2 \\
\hline
\end{tabular}

Source: Annual Reports of the respective concerns for the respective years.

\section{Interpretation:}

Return on Capital Employed indicates the company has yielded on the capital employed for each rupee invested. From Table 7 cited above it could be concluded that the selected housing finance company are in volatility during the selected period of the study. The average of HDFC housing finance had the best Return on Capital Employed (0.06) when compared to HUDCO (0.04), PNB housing finance (0.02), LIC housing finance (0.02), and Dewan housing finance company are unfavorable in 2018 to 20 as an average of (-0.14). it means that significantly less amount of profits are generated by each rupee invested in the capital employed.

\section{C.2. Net profit Margin ratio}

Net profit margin ratio: Profit/Loss After Tax And Before Extraordinary Items /Revenue From Operations

Table 8: Showing the Net Profit Margin Ratio

\begin{tabular}{|c|c|c|c|c|c|c|c|c|c|c|c|c|}
\hline \multirow[t]{2}{*}{ HFC } & \multicolumn{12}{|l|}{ Years } \\
\hline & $\begin{array}{l}2010- \\
11\end{array}$ & $\begin{array}{l}2011- \\
12\end{array}$ & $\begin{array}{l}2012- \\
13\end{array}$ & $\begin{array}{l}2013- \\
14\end{array}$ & $\begin{array}{l}2014- \\
15\end{array}$ & $\begin{array}{l}2015- \\
16\end{array}$ & $\begin{array}{l}2016- \\
17\end{array}$ & $\begin{array}{l}2017- \\
18\end{array}$ & $\begin{array}{l}2018- \\
19\end{array}$ & $\begin{array}{l}2019- \\
20\end{array}$ & Average & Rank \\
\hline HDFC & 0.28 & 0.24 & 0.23 & 0.23 & 0.22 & 0.24 & 0.23 & 0.27 & 0.22 & 0.30 & 0.25 & 1 \\
\hline LIC & 0.21 & 0.15 & 0.14 & 0.14 & 0.13 & 0.13 & 0.14 & 0.13 & 0.14 & 0.12 & 0.14 & 3 \\
\hline Dewan & 0.18 & 0.12 & 0.11 & 0.11 & 0.10 & 0.10 & 0.33 & 0.11 & -0.08 & -1.46 & -0.04 & 5 \\
\hline PNB & 0.19 & 0.16 & 0.14 & 0.11 & 0.11 & 0.12 & 0.13 & 0.15 & 0.16 & 0.09 & 0.13 & 4 \\
\hline HUDCO & 0.24 & 0.23 & 0.24 & 0.25 & 0.23 & 0.24 & 0.24 & 0.20 & 0.22 & 0.23 & 0.23 & 2 \\
\hline
\end{tabular}

Source: Annual Reports of the respective concerns for the respective years. 


\section{International Advanced Research Journal in Science, Engineering and Technology}

Vol. 8, Issue 6, June 2021

DOI: $10.17148 /$ IARJSET.2021.8623

\section{Interpretation:}

Net profit margin is the ratio that measures effectively a company operates the net profit to revenues. From table 8 , it could be concluded that the selected housing finance company are unstable during the selected period for the study. Table 8, The HDFC(0.25) is more effectively control its cost when compared to HUDCO (0.23), LIC housing finance(0.14), PNB housing finance (0.13), and at last Dewan housing finance (-0.37) negative, It indicates that they spending more money then revenue. Therefore, it results that the selected housing companies are effectively controlled its cost expect Dewan housing finance.

Table 9. Ranking on the Profitability Ratio

\begin{tabular}{|l|l|l|l|l|l|}
\hline Ratios & HDFC & LIC & DEWAN & PNB & HUDCO \\
\hline $\begin{array}{l}\text { Average return on capital } \\
\text { employed }\end{array}$ & 0.06 & 0.02 & -0.14 & 0.02 & 0.04 \\
\hline Rank & 1 & 4 & 5 & 3 & 2 \\
\hline $\begin{array}{l}\text { Average Net profit margin } \\
\text { ratio }\end{array}$ & 0.25 & 0.14 & -0.04 & 0.13 & 0.23 \\
\hline Rank & 1 & 3 & 5 & 4 & 2 \\
\hline Overall group ranking & 1 & 3.5 & 5 & 3.5 & 2 \\
\hline
\end{tabular}

On the overall ranking of 2 parameters in profitability ratio, we can say that HDFC(1) was at the first position followed by a HUDCO(2), there is a tie between PNB and LIC(3.5), and Dewan has the least(5) of all the HFCs because of its unfavorable performance in terms of profitability ratio.

\section{Revenue Ratio}

\section{D.1. Total Assets Turnover Ratio}

Total Assets turnover ratio: Revenue From Operations/ Average total assets

Table 10: Showing the Total Assets Turnover Ratio

\begin{tabular}{|c|c|c|c|c|c|c|c|c|c|c|c|c|}
\hline \multirow[t]{2}{*}{ HFC } & \multicolumn{12}{|l|}{ Years } \\
\hline & $\begin{array}{l}\text { 2010- } \\
11\end{array}$ & $\begin{array}{l}\text { 2011- } \\
12\end{array}$ & $\begin{array}{l}2012- \\
13\end{array}$ & $\begin{array}{l}2013- \\
14\end{array}$ & $\begin{array}{l}\text { 2014- } \\
15\end{array}$ & $\begin{array}{l}2015- \\
16\end{array}$ & $\begin{array}{l}\text { 2016- } \\
17\end{array}$ & $\begin{array}{l}2017- \\
18\end{array}$ & $\begin{array}{l}2018- \\
19\end{array}$ & $\begin{array}{l}2019- \\
20\end{array}$ & Average & Rank \\
\hline HDFC & 0.07 & 0.08 & 0.08 & 0.08 & 0.08 & 0.07 & 0.07 & 0.08 & 0.07 & 0.08 & 0.07 & 2 \\
\hline LIC & 0.00 & 0.07 & 0.07 & 0.07 & 0.07 & 0.07 & 0.07 & 0.06 & 0.07 & 0.06 & 0.06 & 4 \\
\hline Dewan & 0.08 & 0.09 & 0.10 & 0.09 & 0.08 & 0.08 & 0.08 & 0.07 & 0.08 & 0.06 & 0.08 & 1 \\
\hline PNB & 0.00 & 0.08 & 0.01 & 0.08 & 0.08 & 0.08 & 0.00 & 0.07 & 0.06 & 0.06 & 0.05 & 5 \\
\hline HUDCO & 0.01 & 0.08 & 0.07 & 0.07 & 0.07 & 0.06 & 0.06 & 0.06 & 0.06 & 0.07 & 0.06 & 3 \\
\hline
\end{tabular}

Source: Annual Reports of the respective concerns for the respective years.

\section{Interpretation:}

The total Assets Turnover ratio measures the value of revenue relative to the value of the assets. Table 10, shows the average of selected housing finance companies Dewan (0.08) is more efficient in generating revenue from its assets. When compared to HDFC housing finance (0.07), HUDCO (0.06), LIC Housing Finance (0.06), and PNB (0.05) respectively. Therefore, the selected housing finance company is efficient in the management and utilization of the assets. Even though some low asset turnover ratios are indicating the underutilization of available resources and the presence of idle capacity.

\section{D.2. Equity Turnover Ratios}

Equity turnover ratio Revenue From Operations [Net]/ Average Shareholders Equity

Table 11: Showing the Equity Turnover Ratio

\begin{tabular}{|c|c|c|c|c|c|c|c|c|c|c|c|c|}
\hline \multirow[t]{2}{*}{ HFC } & \multicolumn{12}{|l|}{ Years } \\
\hline & $\begin{array}{l}2010- \\
11\end{array}$ & $\begin{array}{l}\text { 2011- } \\
12\end{array}$ & $\begin{array}{l}2012- \\
13\end{array}$ & $\begin{array}{l}2013- \\
14\end{array}$ & $\begin{array}{l}\text { 2014- } \\
15\end{array}$ & $\begin{array}{l}2015- \\
16\end{array}$ & $\begin{array}{l}\text { 2016- } \\
17\end{array}$ & $\begin{array}{l}2017- \\
18\end{array}$ & $\begin{array}{l}\text { 2018- } \\
19\end{array}$ & \begin{tabular}{|c|}
$2019-$ \\
20
\end{tabular} & Average & Rank \\
\hline HDFC & 0.52 & 0.64 & 0.66 & 0.62 & 0.62 & 0.61 & 0.60 & 0.58 & 0.43 & 0.49 & 0.58 & 4 \\
\hline
\end{tabular}


Vol. 8, Issue 6, June 2021

\section{DOI: 10.17148/IARJSET.2021.8623}

\begin{tabular}{|l|l|l|l|l|l|l|l|l|l|l|l|l|}
\hline LIC & 0.84 & 0.87 & 0.85 & 0.90 & 0.93 & 1.00 & 0.95 & 0.86 & 0.83 & 0.77 & 0.88 & 1 \\
\hline Dewan & 0.88 & 0.96 & 1.11 & 0.99 & 1.01 & 1.02 & 0.98 & 0.84 & 0.10 & 0.17 & 0.81 & 2 \\
\hline PNB & - & 0.86 & 0.93 & 1.03 & 1.03 & 1.02 & 0.79 & 0.63 & 0.68 & 0.67 & 0.76 & 3 \\
\hline HUDCO & 0.29 & 0.32 & 0.31 & 0.29 & 0.30 & 0.31 & 0.35 & 0.29 & 0.36 & 0.44 & 0.33 & 5 \\
\hline
\end{tabular}

Source: Annual Reports of the respective concerns for the respective years.

\section{Interpretation:}

The equity turnover ratio measures the proportion contribution of revenue to its stockholders' equity. From Table 11, it could be stated that the average of selected housing finance company LIC housing finance (0.88) higher contribution of shareholders equity use. when compared to Dewan housing finance (0.81), PNB housing finance (0.76), HDFC housing finance $(0.58)$, and HUDCO housing finance $(0.33)$. Therefore, the higher contribution of shareholders to the revenue a the housing finance companies get a better long-term solvency position.

Table 12. Ranking on the Revenue Ratio

\begin{tabular}{|l|l|l|l|l|l|}
\hline Ratios & HDFC & LIC & DEWAN & PNB & HUDCO \\
\hline Average total assets turnover ratio & 0.07 & 0.06 & 0.08 & 0.05 & 0.06 \\
\hline Rank & 2 & 4 & 1 & 5 & 3 \\
\hline Average equity turnover ratio & 0.58 & 0.88 & 0.81 & 0.76 & 0.33 \\
\hline Rank & 4 & 1 & 2 & 3 & 5 \\
\hline Overall group ranking & 3 & 2.5 & 1.5 & 4 & 4 \\
\hline
\end{tabular}

On the overall ranking of 2 parameters in revenue ratio, we can say that Dewan housing finance (1.5) was at the first position followed by a LIC (2.5), HDFC (3) and there is a tie between PNB and HUDCO (4) was the least of all the HFCs because of its generators less revenue from its operation.

\section{OVERALL RANKING}

The overall ranking is based on the average of the ratios calculated which are Efficiency, Liquidity, Revenue, and Profitability over a period of 10 years from 2010 to 2020.

Table 13. Overall Ranking on the Financial Ratio

\begin{tabular}{|l|l|l|l|l|l|}
\hline Ratios & HDFC & LIC & DEWAN & PNB & HUDCO \\
\hline Liquidity ratio & 2.5 & 5 & 2.5 & 3 & 2 \\
\hline Efficiency ratio & 2 & 4.5 & 4 & 3.5 & 1 \\
\hline Profitability ratio & 1 & 3.5 & 5 & 3.5 & 2 \\
\hline Revenue ratio & 3 & 2.5 & 1.5 & 4 & 4 \\
\hline Average & $\mathbf{2 . 1}$ & $\mathbf{3 . 9}$ & $\mathbf{3 . 3}$ & $\mathbf{3 . 5}$ & $\mathbf{2 . 3}$ \\
\hline Relative Overall Ranking & $\mathbf{1}$ & $\mathbf{5}$ & $\mathbf{3}$ & $\mathbf{4}$ & $\mathbf{2}$ \\
\hline
\end{tabular}

We can see that the first position is obtained by HDFC which has an average overall ranking of 2.1 under financial ratio analysis followed by HUDCO which secures the second position. The third rank is obtained by DHFL. The last position is secured by LICHFL with an average overall ranking of 3.9.

\section{ANALYSIS OF THE CURRENT FINANCIAL POSITION FOR FUTURE SCENARIOS}

The above study describes the financial performance of a selected housing finance company by using liquidity, efficiency, revenue, and profitability parameters for the period of 10 years for the analysis. it could be found that the liquidity position of some selected housing finance companies has been not satisfied for generating cash to meet the short-term obligation, There are using more outside funds when compared to the owner fund. it leads to the potential risk of the company, there is less return from the capital investment, it indicates that there is no control against costs and The company is not utilizing the assets for the revenue generation. If the company is managing the operational and financial activities by the better management plans long and short investments to ensure efficiency and effectiveness so that they can avoid a liquidity crunch happened in Dewan housing finance Ltd. By mismatch in short term and long term management and now we facing a covid -19 pandemic situation, there is moratorium benefit affects the housing finance companies by reducing the cash flows and increasing the non-performing assets. like this situation or any other 


\section{DOI: $10.17148 /$ IARJSET.2021.8623}

crisis in the future scenarios. As a final mark on their point, it could be stated that it has improved a lot from the year 2010 to 2020 .

\section{CONCLUSION}

During the process of evaluation of the financial performance of the selected housing finance company, the study highlighted that the housing finance companies have obtained different ranks with respect to ratios analysis. the relative overall ranking of selected housing finance companies, the first position is obtained by HDFC which has an average overall ranking of 2.1 followed by HUDCO which secures the second position. The third rank is obtained by DHFL. The last position is secured by LICHFL with an average overall ranking of 3.9.

\section{REFERENCES}

[1]. https://www.hdfc.com/investor-relations\#annual-reports from the year 2010 to 2020 .

[2]. https://www.lichousing.com/annual_report.php from the year 2010 to 2020.

[3]. https://www.pnbhousing.com/investor-relations/annual-reports/ from the year 2010 to 2020

[4]. https://hudco.org/writereaddata/ar19.pdf from the year 2010-2020

[5]. https://www.dhfl.com/investors/annual-reports from the year 2010 to 20.

[6]. https://nhb.org.in/wp-content/uploads/2021/03/Companies-HFCs-with-asset-size-of-100-crore-n-above.pdf

[7]. Meghna Sarda \& Ramesh Chandra babu, (2018) in their study titled“financial performance analysis of selected Indian NBFCs in housing finance" IJCRT1802588 International Journal of Creative Research Thoughts (IJCRT) www.ijcrt.org 1151

[8]. K, B. G., \& Ahuja, N. (2020). Financial Performance of Housing Finance Companies in India. 7(13), 2265-2281

[9]. Satyanarayana, S. ., \& Ramu, S. (2019). A Comparative Study between Public and Private Housing Finance Companies (HFCs) in India. International Journal of Engineering and Management Research, 9(3), 138-141. https://doi.org/10.31033/ijemr.9.3.17 